\title{
SPOSÓB POSTRZEGANIA SACRUM W ARCHITEKTURZE WSPÓŁCZESNEJ
}

\author{
Michał Dmitruk \\ Wydział Budownictwa i Architektury, Katedra Architektury, Urbanistyki \\ i Planowania Przestrzennego, Politechnika Lubelska \\ Faculty of Civil Engineering and Architecture, Department of Architecture, \\ Urban and Spatial Planning, Lublin University of Technology \\ e-mail: m.dmitruk@pollub.pl
}

\begin{abstract}
Streszczenie. Od świtu ludzkości, czasów organizowania się i gromadzenia wspólnot osadniczych, poprzez czasy formowania się pierwszych miast, towarzyszyła człowiekowi wiara w różnorodne bóstwa ${ }^{1}$. Wraz z rozwojem kulturowym i społecznym także systemy wierzeń ulegały ujednolicaniu, kodyfikacji i przyciągały coraz większą liczbę wiernych, stając się czynnikiem społeczno-politycznym wpływającym istotnie na kształt i kierunki rozwoju młodych cywilizacji. Wraz ze wzrostem znaczenia nowych idei, organizacji przez nie przestrzeni sacrum i formalizacji zachowań, zaczęto kult „przekuwać w kamień”2. Analizując architekturę sakralną każdej epoki i studiując jej historię, można zaobserwować jak zmieniała się sinusoida stosunków społecznych pomiędzy tolerancją i religijnym współistnieniem z jednej strony, a nienawiścią i dążeniem do dominacji z drugiej. We współczesnym, bardzo zróżnicowanym, pełnym mnogości wyznań i różnic kulturowych świecie, architekci stają przed wyzwaniem w jaki sposób kształtować architekturę sakralną aby służyła pokojowej koegzystencji, akceptowaniu różnic, nie będąc jednocześnie zarzewiem konfliktów, wzajemnych roszczeń i pretensji.
\end{abstract}

Słowa kluczowe: architektura, religia, sacrum, społeczeństwo, cywilizacja, współczesność, konflikt, tolerancja.

\section{WPROWADZENIE}

W przestrzeni niejednorodnej pod względem religijnym, kwestia wiary często prowokuje powstawanie podziałów społecznych. Historia dostarcza dowodów różnego podejścia społeczeństw do owych różnic. Ich tłem zwykle jest architektura sakralna, a stosunek wobec świątyń często jest czynnikiem determinującym, lub przynajmniej odzwierciedlającym relacje panujące pomiędzy wyznawcami różnych religii. Od początków historii cywilizacji ludzkiej obserwować można różne podejście wyznawców rozmaitych religii do siebie nawzajem od pokojowej koegzystencji do wojen i konfliktów, trwających niejednokrotnie do czasów dzisiejszych. Architektura sakralna, od czasów starożytnych, zaczęła pełnić istotną funkcję w społeczeństwie, materializować, unaoczniać i utrwalać poglądy do tej pory dostępne jedynie pozazmysłowo. Wraz z rozwojem cywilizacyjnym człowieka, architektura stała się nieodłącznym elementem religii - odzwierciedleniem jej charakteru. Obrazowała koegzystencję różnych wyznań lub też unaoczniała supremację jednego nad drugim. Domy Boże były zawsze miejscem, które gruntowało pozycję danego kultu w określonej społeczności. Świątynia przez wieki, postrzegana była bardziej za dzieło natchnione boską wolą, niż za efekt kolektywnej pracy ludzkiej. Górowała często nad miastami, dodając im splendoru i podnosząc ich znaczenie. Między społecznościami pojawiała się nawet rywalizacja, gdzie powstanie większa i piękniejsza świątynia. W przypadku konfliktu, to miejsca kultu jako pierwsze były transformowane według własnych wierzeń, bądź zwyczajnie bezczeszczone w celu ukazania dominacji nad podbitym ludem. Podobnych przykładów swoistego religijnego „wyścigu zbrojeń”, gdzie świątynie stawały się kartą przetargową, w historii ludzkości można znaleźć bardzo

1 Bergson H.,1993. Dwa źródła moralności i religii, Kraków, s. 105.

2 Murat M., wykład z filozofii na Uniwersytecie Przyrodniczym w Lublinie. 
wiele. Począwszy od realizacji epokowej wręcz świątyni Hagia Sophia w Konstantynopolu ${ }^{3}$ i znamiennych słów jej twórcy, cesarza Justyniana: „Prześcignąłem Cie Salomonie”, przez chichot historii w postaci przebudowy w 1453 roku owego kościoła na meczet ${ }^{5}$, aż po barbarzyńskie i znamienne w skutkach zburzenie przez Talibów majestatycznych posągów Buddy w Baimanie w 2001 roku. Historia daje architektom cenną lekcję na temat formy i funkcji społecznej architektury sakralnej. Zarówno religia, jak i architektura ulegają przeobrażeniom, trendom i zmianom w obyczajowości danych społeczności. Zmieniają się wraz z duchem czasu lub uparcie trwają w miejscu niejako na przekór nowoczesności.

We współczesnym świecie konieczność współistnienia różnych kultur i religii jest nie tylko problematyczną sytuacją zastaną, ale także jedyną szansą na pokojowy rozwój i przyszłość cywilizacji ludzkiej. Sytuacja ta zmusza do poszukiwań odpowiednich form wyrażania wiary, zarówno w sferze społecznej koegzystencji oraz w formie współczesnej architektury sakralnej.

\section{SACRUM BEZ BOGA}

Architektura sakralna nie musi bezpośrednio wiązać się z przedmiotem wiary, lub wyznawanym kultem, czy religią. Epoka oświecenia przyniosła rewolucję w sposobie pojmowania religii. Ideały i obyczaje na przestrzeni wieków nowożytnych, niemal jak w szachownicy, naprzemiennie zwracały się ku racjonalizmowi, popartemu rozumem i nauką lub ku pełnemu uprzedzeń i zabobonów, romantycznemu idealizmowi. Podobnie jak dwa wieki wcześniej w epoce renesansu, myśl ludzka „wieku rozumu” skierowała się w stronę tego pierwszego. Europejska myśl religijna wyzbyła się przesądów, zyskując abstrakcyjną, czystą formę. Wielu myślicieli ery oświecenia porzuciło całkowicie deistyczną koncepcję Stwórcy i zaczęło poszukiwać swojego sacrum w sferze działalności człowieka, jego wytworach cywilizacyjnych i dokonaniach. Pokłosiem tych nowych, obrazoburczych idei stała się między innymi koncepcja budowy w Paryżu zupełnie świeckiej świątyni: Panteonu Wielkich Ludzi ${ }^{7}$. Religijna funkcja budynku, który początkowo miał być kościołem św. Genowefy, nie została zaakceptowana przez Francuskie Zgromadzenie Narodowe, które zadecydowało w 1790 roku, że budynek stanie się narodowym muzeum ${ }^{8}$. Ten gigantyczny „pomnik na cześć ludzkości” wybudowano w stylu neoklasycystycznym - bardzo uporządkowanym i czystym w formie, na planie krzyża, z centralnie umieszczoną kopułą i kolumnowym portykiem, zwieńczonym frontonem na wzór Rzymskiego Panteonu. W 1837 roku nad portykiem umieszczono ozdobny napis: Aux Grands Hommes La Patrie Reconnaissante ${ }^{9}$. Od tamtej pory budynek stanowi świątynię postępowej myśli, świeckiego miejsca dedykowanego wielkim osobom i wartościom ponadczasowym. W krypcie Panteonu znajdują się m.in. grobowce: Woltera, Jana Jakuba Rousseau, Victora Hugo, Emila Zoli, wynalazcy pisma dla niewidomych Louisa Braille'a, czy Marii Skłodowskiej-Curie.

Patrząc na słowo „rewolucja” (francuska, rosyjska czy seksualna) poprzez pryzmat historii, zwykle przywołuje to konotacje z silnie areligijną i antykościelną postawą jej przedstawicieli. Pomnikiem, a zarazem siedzibą III Międzynarodówki komunistycznej zakładano, że będzie

3 Obecnie Stambuł, Turcja

4 Różycka-Bryzek A.,2002. Encyklopedia Kultury Bizantyńskiej, Warszawa.

5 Ibidem.

6 Dominik-Stawicka D., 2012. Vademecum, Język Polski. Operon, s. 90

7 Za: Kosiński W.,2011. Architektura sacrum wobec konfliktów, tolerancji i pojednania. Historia, współczesność, perspektywy, Przestrzeń i forma, nr 15/2011, Czasopismo naukowo-dydaktyczne Polskiej Akademii Nauk oraz Zachodniopomorskiego Uniwersytetu Technologicznego w Szczecinie.

8 Burleigh M., 2005. The French Revolution and the Catholic Church.Harper Collins. Nowy Jork.

9 Aux Grands Hommes La Patrie Reconnaissante (fr.) Wielkim Ludziom Wdzięczna Ojczyzna 
olbrzymia 400 metrowa wieża autorstwa rosyjskiego malarza i architekta Włodzimierza Tatlina. Ta monstrualna, czerwona, stalowa konstrukcja miała ukazywać szczyt możliwości konstrukcyjnych i talentów inżynieryjnych człowieka. Miała przewyższać wieżę Eiffla i pokazywać dominację nad zepsutą i zacofaną kulturą zachodu, a także pokazywać wyższość proletariatu i systemu socjalistycznego. Wewnątrz miały znajdować się biura i kancelarie światowego ruchu komunistycznego. Konstrukcja, określona przez prof. Wojciecha Kosińskiego mianem „katedry bezbożnictwa”10, była przesycona rozmaitą symboliką. Kolor czerwony nawiązywać miał do barw rewolucji bolszewickiej. Swoim rozmiarem i rozmachem z jakim została zaprojektowana miała ukazywać nieograniczoną wprost moc twórczą „,człowieka pracy” i sięgać wyżej niż ktokolwiek, kiedykolwiek sięgnął. Najwyraźniejszą i najbardziej charakterystyczną inspiracją jest jednak nawiązanie w formie do Biblijnej wieży Babel, w jej archetypicznej, utrwalonej na płótnie Pietera Bruegla formie. Forma ta wybrana została nieprzypadkowo. Wieża Tatlina, podobnie jak wieża Babel miała być dziełem kolektywnej pracy ludzi, kreacją czysto ludzką, bez boskiej interwencji, sięgającą niemalże do nieba. Konstrukcja miała pokazać, że mocą inżynierów i wspólnej pracy ludzi, bez ingerencji sił nadprzyrodzonych, można wytworzyć dzieła równe boskim, a wystarczy do tego tylko rozum i praca. Miała być to świątynia w swojej pysze dedykowana ku czci człowieka. Budowla nie została zrealizowana z przyczyn o wiele bardziej przyziemnych, niż klęska wieży Babel - w wyniszczonej I Wojną Światową Rosji zwyczajnie brakowało materiałów i środków pieniężnych na jej realizację.

Współczesne „sacrum bez Boga” nie obnosi się pychą i nie walczy z Bogiem. Nie jest też wyniosłe i majestatyczne w formie - ma zupełnie inny charakter. Jest raczej miejscem wyciszenia, charakterystycznego nastroju skupienia i zadumy. Próbuje być inspiracją dla ludzi poszukujących sacrum w niezdefiniowanej odgórnie formie. Przykładem takiego cichego sacrum może być rzeźba Singing Ringing Tree ${ }^{11}$ ustawiona na wzgórzu w Lancashire w Wielkiej Brytanii. Zaprojektowana przez Mike`a Tonkin`a i Annę Liu trzymetrowa rzeźba ze stalowych rur skonstruowana jest w taki sposób, aby przepływający przez tuby wiatr wydawał zmieniający się, spokojny, harmoniczny i nieco mistyczny w charakterze dźwięk. Przywołując skojarzenia z biblijnym gorejącym krzewem, którego formę przybrał Bóg ${ }^{12}$, drzewo z Lancashire zdaje się również jakby miało coś do powiedzenia. Delikatne dźwięki wprowadzają w stan wyciszenia i nastroju kontemplacji. Takie nowatorskie i zupełnie odmienne od dotychczasowego podejście do sfery sacrum jest czymś bardzo cennym we współczesnym, pełnym zgiełku i natłoku bodźców świecie. Ludzie zmęczeni hałaśliwym i agresywnym, zarówno sacrum jak i profanum, zaczynają szukać świętości w skupieniu, wyciszeniu - we własnych rozmyślaniach.

\footnotetext{
10 Kosiński W.,2011. Architektura sacrum wobec konfliktów, tolerancji i pojednania. Historia, wspótczesność, perspektywy, Przestrzeń i forma, nr 15/2011, Czasopismo naukowo-dydaktyczne Polskiej Akademii Nauk oraz Zachodniopomorskiego Uniwersytetu Technologicznego w Szczecinie.

11 Nagrany dźwięk, do usłyszenia pod adresem http://www.youtube.com/watch?v=4B0hGyKV9qs, Stan z dn.01.01.2015.

12 Księga Wyjścia, 3,1-21;4,1-14/ Biblia Tysiaclecia,1965. Pallotinum, Poznań.
} 


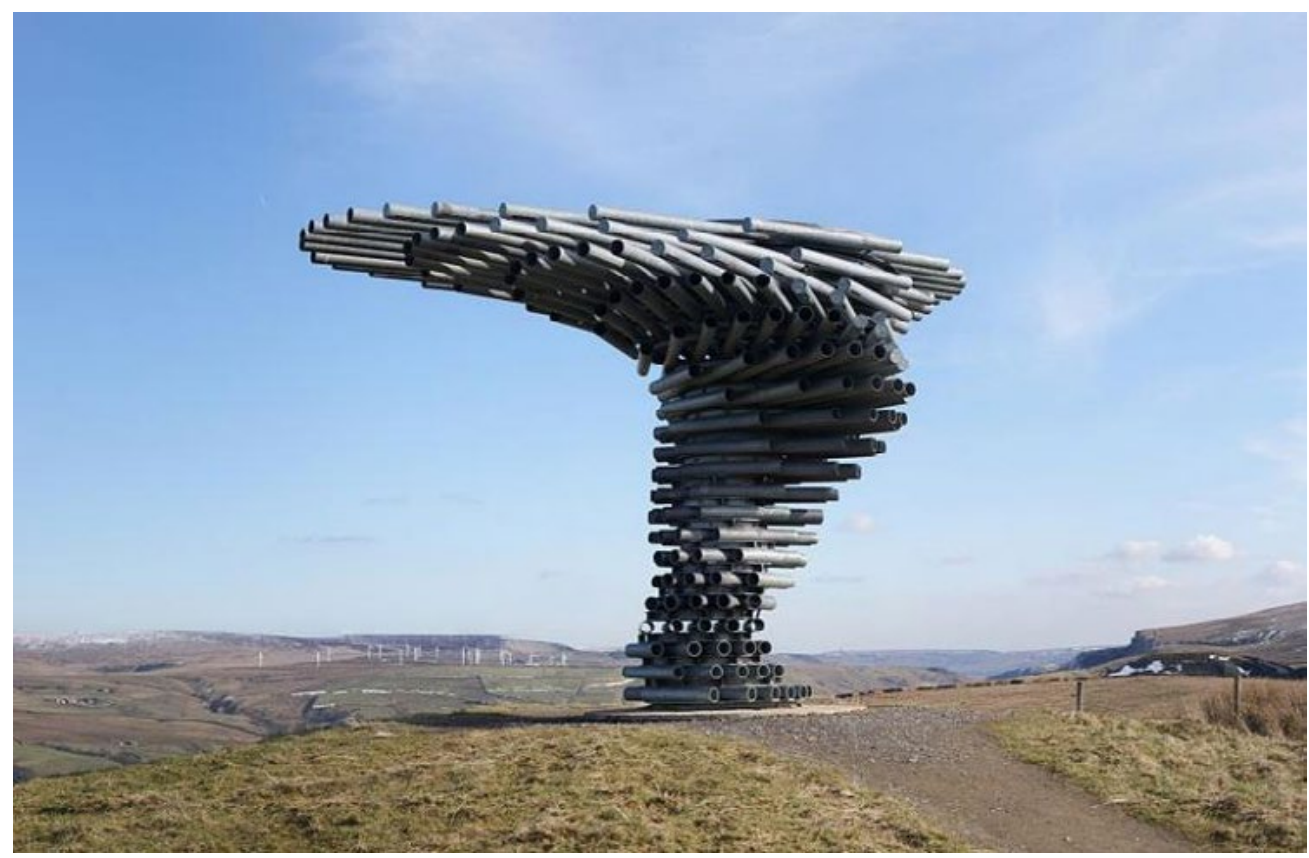

Ryc. 1. Singing Ringing Tree w Lancashire w Wielkiej Brytanii autorstwa Mike`a Tonkin`a i Anny Liu. Źródło: wikipedia.pl

Fig. 1. Singing Ringing Tree, Lancashire, Great Britain. Authors: Mike Tonkin and Anna Liu. Source: wikipedia.pl

\section{SPOSÓB POSTRZEGANIA SACRUM W ARCHITEKTURZE WSPÓŁCZESNEJ}

Obserwując zmiany zarówno w podejściu człowieka do kwestii wiary, jak i do samej architektury sakralnej zauważyć można wyraźne tendencje ekumeniczne w sposobie kształtowania współczesnych świątyń i próby łączenia w sposób synkretyczny obecnie dość istotnie różniących się wyznań. Potrzeba tolerancji i pojednania między wyznaniami, szczególnie silna po ciężkich doświadczeniach XX wiecznych totalitaryzmów, mobilizowała do podejmowania prób realizacji świątyń, umożliwiających współistnienie i wspólne poszukiwanie sacrum, niezależnie od różnic. Przykładem jednej z takich realizacji może być Kaplica Korony Cierniowej w Eureka Springs w USA, autorstwa Euine`a Fay`a Jonesa. Schowana wśród wzgórz kaplica, w niczym nie przypomina znanych powszechnie świątyń. Będąc wewnątrz budynku o ażurowej, drewniano - stalowej konstrukcji wypełnionej szkłem ma się wrażenie bycia pośrodku lasu, wśród natury. Wnętrze budynku również nie jest specjalnie przystosowane do odprawiania żadnego znanego obrządku. Nie ma tam ołtarza, mównicy, separacji strefy wiernych i kapłanów a jedynie pulpit, na którym leży Biblia. Kluczowym dla zrozumienia idei przyświecającej temu domowi modlitwy jest dedykacja, brzmiąca: „Wszystkim ludziom dobrej woli, także niewierzącym". Kaplica o prostej, ale subtelnej i idealnie wpisanej w krajobraz okolicy bryle ma służyć kontemplacji, i wyciszeniu zarówno osobom wierzącym oraz wątpiącym i poszukującym. Wrażenia z wnętrza świątyni w ten sposób opisuje dr. Anna Szafranek z Politechniki Lubelskiej: $W$ czasie zwiedzania trafiliśmy na śpiew psalmów w wykonaniu jakiejś kobiety. Jej piękny głos i śpiewany utwór wyciszyt nas. Po ustyszeniu ostatniego wersu pieśni religijnej nikt się nie poruszyt, siedzieliśmy jak zaczarowani. Ta cisza i bezruch byta naturalnym przedlużeniem przeżywanego piękna śpiewu i nastroju. Dopiero po dtuższej chwili 
rozległy się brawa i stuchacze podchodzili do solistki wyrażając swoje uznanie lub opisując doznane wrażenia. ${ }^{13}$

Fenomenalnym przykładem wyjątkowego wyczucia formy i swoistej gry delikatnym nastrojem sacrum jest kościół Votum Aleksa w Tarnowie w Polsce, autorstwa młodej polskiej pracowni projektowej „Beton”. Minimalistyczna do granic, drewniana konstrukcja w całości pokryta gontem przybiera skromny, archetypiczny kształt chrześcijańskiej kaplicy. Kościół znajduje się na skarpie, na brzegu rzeki Wisły i otoczony jest dookoła zielenią, z którą idealnie współgra. W projekcie widać doskonałe dopasowanie do otaczającego spokojnego i naturalnego krajobrazu, prowokując nastrój wyciszenia, kontemplacji i pokory. Zarówno wewnątrz jak i na zewnętrz brak jest jakiejkolwiek ornamentyki, a przynależność religijną określa jedynie skromny, niewielki krzyż na kalenicy dachu. Sam ołtarz jest prostym drewnianym stołem, umieszczonym na tym samym poziomie co ławy wiernych, a tło ołtarza stanowi obszerne przeszklenie - zabieg ten zbliża kapłana do zgromadzonych. Tradycyjna technologia wykonania budynku z belek drewnianych dała okolicznym mieszkańcom, o ograniczonym warsztacie technicznym, możliwość współrealizacji przedsięwzięcia i zbiorowego zaangażowania w budowę. Sami projektanci wypowiadają się o świątyni w następujący sposób: „Chcieliśmy przekazać mieszkańcom wsi budynek, który mogliby polubić. Uznaliśmy więc, że zbyt daleko posunięte poszukiwania w sferze formy nie maja tu sensu. Ograniczyliśmy się do znajomych skadinad ksztaltów i rozwiązań (dach dwuspadowy, prosta bryła) - z tym, że wszystko pociag nęliśmy dalej niż gdybyśmy budowali zwykly dom. Kościół jest bardzo smukly, wysoki, ma skomplikowana drewniana konstrukcję, w ścianach nie ma okien, a jedynym przeszkleniem pozostaje ściana szczytowa stanowiaca tło dla ołtarza. Przez tę ścianę widać daleki wiślany horyzont. Dzięki temu ktoś, kto znajduje się w środku, może łatwiej znaleźć wyciszenie, może w spokoju oddać się kontemplacji natury, modlitwie „,14. Zgodnie z założeniami projektowymi, „sacrum” w budynku jest ciche, spokojne, nieprzytłaczające. Dostępne dla tych osób, które rzeczywiście poszukują nastroju sprzyjającego kontemplacji. Wystrój tej świątyni nic nie narzuca, do niczego nie prowokuje - pozwala osobiście i bez przymusu doświadczyć obecności Boga.

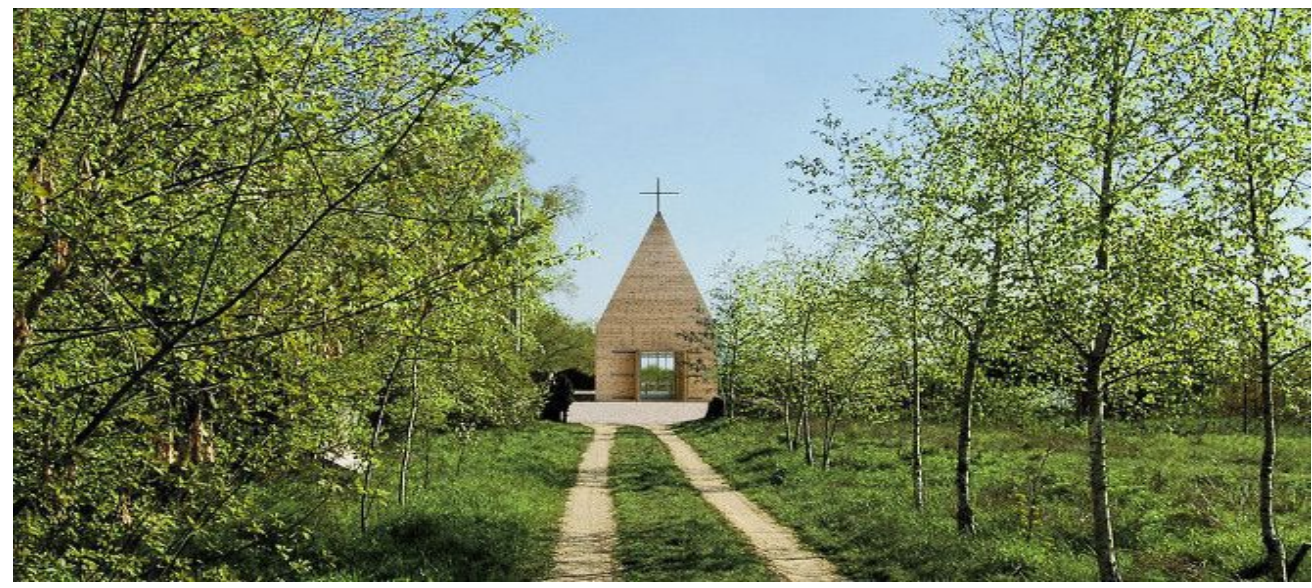

Ryc. 2. Votum Aleksa w Tarnowie, autorstwa pracowni projektowej „Beton”. Źródło: sztuka-architektury.pl

Fig. 2. Alex`s Votum chapel in Tarnów, Poland. Author: "Beton” design studio. Source: sztuka-architektury.pl

13 Fragment relacji z podróży Anny Szafranek. ,,Moje spotkanie z Ameryką”, Biuletyn informacyjny Politechniki Lubelskiej 2(12) 2004. Lublin.

14 Wywiad projektantów dla portalu bryła.pl z dn.03.07.2009 - Stan z dnia 01.01.2015 
Współczesny świat nie stanął w ofensywie wobec wartości duchowych, zmienił jedynie podejście do kwestii związanych z kultywowaniem religii. Proces pluralizacji kulturowej uświadomił człowiekowi że właściwym kierunkiem rozwoju duchowego i cywilizacyjnego jest życie w poszanowaniu innych wierzeń i tradycji. Swoista nieufność społeczna i budujący się dystans wobec zorganizowanej formy wierzeń i instytucji religijnych było przyczynkiem do wejścia ludzi w sferę swoistego „,cichego sacrum”"15, gdzie wiara kontemplowana jest indywidualnie i interpretowana poprzez pryzmat swojej osoby. Doskonałym przykładem współczesnego podejścia do architektury sakralnej, świadomym powyższych procesów może być kościół Chrystusa, Nadziei Świata autorstwa Heinza Tesara, zlokalizowany w biznesowej dzielnicy Wiednia. Swoją oszczędną, elegancką i zachowawczą formą doskonale wkomponowuje się w otoczenie biurowców. Wrażenie swoistego spokoju, pośród głośnego życia miejskiego potęguje brakiem nachalnej ornamentyki który zaprasza do wewnątrz, nie tworząc zbędnych barier psychologicznych. Znaczący jest jedynie niewielki krzyż na elewacji, jednak sama bryła ma charakter ekumeniczny, zachęcający do modlitwy wszystkich wierzących.

Otwartość i postępowość prowadzi do wielu interesujących koncepcji i ich realizacji w obrębie architektury sakralnej. Jak bardzo zmienia się podejście religii i wyznawców do budynków świątynnych najlepiej obrazuje nietypowa i wyjątkowa świątynia zwana Ekumeniczną Kaplicą Sztuki p.w. Św. Henryka w Turku w Finlandiii ${ }^{16}$. Sama nazwa zdaje się być jakąś niedorzeczną zabawą lingwistyczną, a jednak w rzeczywistości świątynia jest również galerią sztuki! Zwięzła w swojej przypominającej odwróconą łódź formie, kaplica idealnie wpasowuje się w okoliczny sosnowy las. Wewnątrz, wzdłuż nawy organizowane są wystawy sztuki, które można oglądać również podczas nabożeństwa. Z jednej strony wnętrze przypomina typowy mały drewniany kościółek, z drugiej zaś tworzy zupełnie niespotykany nastrój, służąc jednocześnie odprawianiu eucharystii, a także wystawom, happeningom i wernisażom, gdzie jedna funkcja nigdy nie stoi na przeszkodzie drugiej, a wręcz współistnieją z wzajemnym poszanowaniem. Te zupełnie innowacyjne, zupełnie liberalne i ponad podziałowe podejście do architektury sakralnej zdaje się bardzo dobrze spełniać swoją rolę i pokazuje, że otwarcie strefy sacrum bardziej w stronę ludzi jest nie tylko możliwe, ale bardzo pożądane. To co się rzeczywiście liczy to wzajemny szacunek i dobra wola. Odnaleźć spokój i ukojenie mogą tam ludzie poszukujący wzniosłych wartości zarówno w Bogu, jak i w sztuce. Projekt w Turku porusza istotną kwestię na temat kształtu i podejścia do kwestii religijnych w XXI wieku. Rodzi się pytanie, czy świątynie powinny znaleźć swoje miejsce pomiędzy butikami w supermarkecie? Kaplice szpitalne już nikogo nie dziwią, a przecież są tak odmienne w charakterze od historycznych wielkich świątyń. Misją współczesnych Kościołów powinno być wyjście do ludzi, otwarcie się na odmienność i pewna postępowość, która powinna dawać możliwość zbliżenia się do sacrum nawet w miejscach pozornie na to nieprzeznaczonych. W hałaśliwym, pełnym bodźców i doświadczeń współczesnym świecie, człowiek naturalnie poszukuje miejsca wyciszenia i introspekcji - świątynie takie jak wspomniane wyżej mogą okazać się właśnie tym, co da mu ukojenie.

15 Dmitruk M.,2012 Wiara a forma - wpływ religii na architekture, [w]: Człowiek Religia Wychowanie, Polianna, Krasnystaw, s. 83-98

16 Ökumenische Kapelle St. Henry, FI-Turku, Architektur \& Technik 2/2007, s. 6-10 


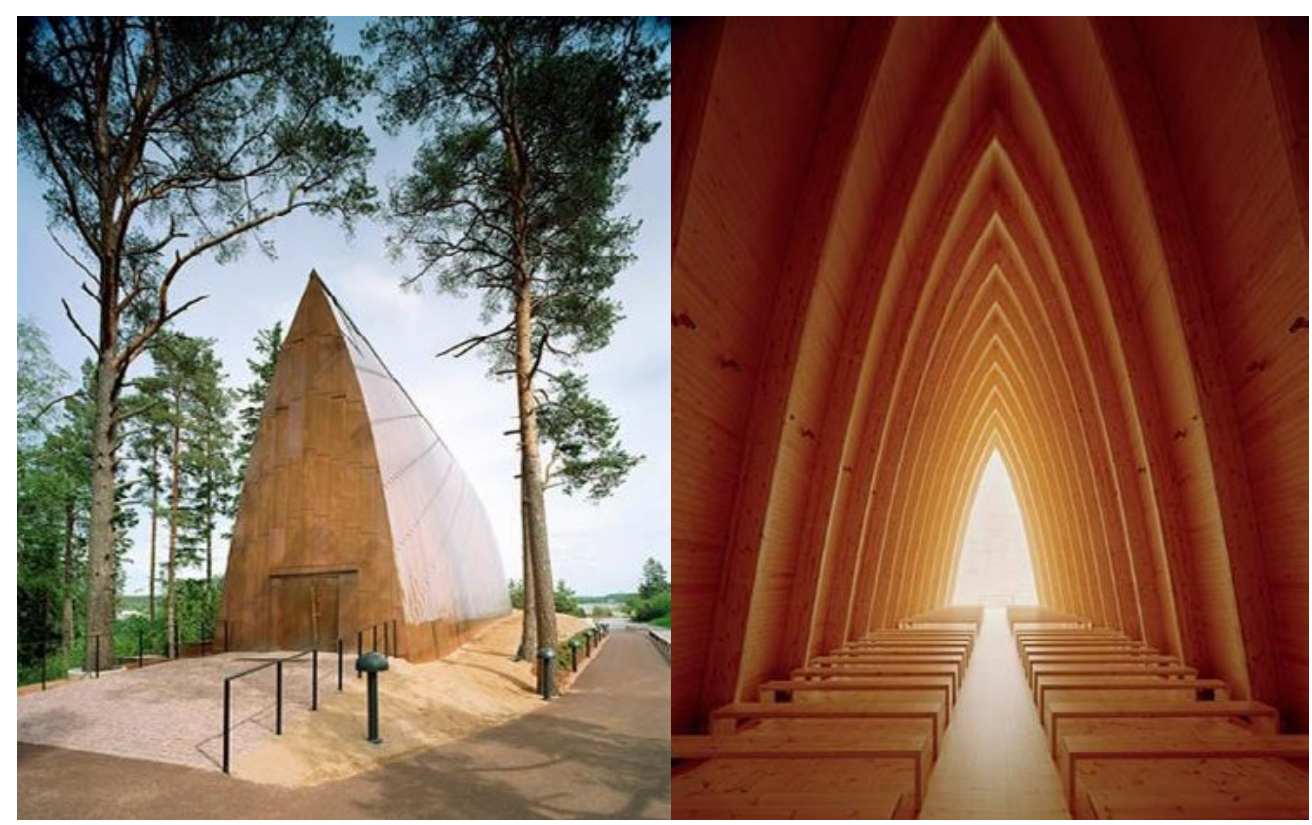

Ryc. 3., 4, Ekumeniczną Kaplicą Sztuki pw. Św. Henryka w Turku w Finlandii. Fot.: J. Tiainen Fig. 3., 4, St. Henry`s Ecumenical Chapel of Art, Turku, Finland. Photo.: J. Tiainen

\section{PODSUMOWANIE}

Podobnych realizacji do przedstawionych w części: „sposób postrzegania sacrum w architekturze współczesnej” jest na świecie coraz więcej. Pokazują że architektura sakralna znów zaczyna odzwierciedlać prądy myślowe i poglądy religijne. Wielokulturowość i różnorodność jest czymś nieuniknionym we współczesnych pluralistycznych społeczeństwach, ale jest też zarówno czymś wyjątkowo wartościowym i unikatowym. Współczesny człowiek odkrył, że różnice nie muszą być impulsem do podziałów, a umiejętność aby się w piękny sposób różnić jest czymś co warto kultywować. Obecnie niejednokrotnie źle pojęta tolerancja przekonuje nas, że jesteśmy wszyscy jednakowi - jednak odpowiedzialnym podejściem jest dostrzeżenie i zaakceptowanie różnic oraz czerpanie obopólnych korzyści ze wspólnych wartości. Przed takim zadaniem stoją architekci, szukający odpowiedzi w kwestii formy współczesnej architektury sakralnej. Przedstawione przykłady pokazują znakomitą odmianę od znanej obecnie pretensjonalnej formuły wielu świątyń. Sacrum w tych wszystkich miejscach jest ciche, spokojne, służy człowiekowi, a nie istnieje jedynie same dla siebie. Jest zupełnie odmienne od współczesnej, wulgarnej w formie architektury - może dlatego właśnie staje się coraz bardziej intrygujące. Realizacje te walczą z postępującym w społeczeństwie wrażeniem zimnej transcendencji Boga i pokazują, że Sacrum jest nadal wokół nas, wystarczy tylko na chwilę się zatrzymać. 


\title{
PIŚMIENNICTWO
}

Bergson H.,1993. Dwa źródła moralności i religii, Kraków, s. 105.

Biblia Tysiaclecia,1965. Wydawnictwo Pallotinum, Poznań

Burleigh, M., 2005. The French Revolution and the Catholic Church, Harper Collins, Nowy Jork.

Dominik-Stawicka D., 2012. Vademecum, Język Polski. Operon, s. 90

Dmitruk M.,2012 Wiara a forma - wptyw religii na architekture, [w]: Człowiek Religia Wychowanie, Polianna, Krasnystaw, s. 83-98

Kosiński W.,2011. Architektura sacrum wobec konfliktów, tolerancji i pojednania. Historia, współczesność, perspektywy, Przestrzeń i forma, nr 15/2011, Czasopismo naukowo-dydaktyczne Polskiej Akademii Nauk oraz Zachodniopomorskiego Uniwersytetu Technologicznego w Szczecinie.

Ökumenische Kapelle St. Henry, FI-Turku, Architektur \& Technik 2/2007, s. 6-10

Różycka-Bryzek A.,2002. Encyklopedia Kultury Bizantyńskiej, Warszawa.

Szafranek A.,2004. Moje spotkanie z Ameryka, Biuletyn Informacyjny Politechniki Lubelskiej 2(12), Lublin.

\section{THE PERCEPTION OF SACRUM IN MODERN ARCHITECTURE}

\begin{abstract}
Since the time of the first settlements and communities, people tend to believe in various deities. Along with the cultural and social development, religion has become codified and popularized amongst the growing number of believers, thus became an important factor in the social and political development. Growing importance of religious beliefs, resulted in organizing sacred spaces which later became churches and temples. Throughout the centuries, religion became a stimulant to unite and cooperate on the one hand, and a root of conflict and intolerance on the other. In present times, architects have to face a diversified beliefs and solve major cultural differences, while designing a contemporary temple. Nowadays designers have to create sacral architecture in a way providing peaceful coexistence and mutual respect between followers.
\end{abstract}

Key words: architecture, society, civilization, religion, modern, conflicts, tolerance. 